\title{
Culture wars and protected areas: narratives against national parks. An exploratory qualitative comparison of the movements opposing Adula Park and Locarnese Park
}

\author{
Mosè Cometta \\ Keywords: cultural hegemony, discursive asynchrony, consensus, communication, Ticino, Switzerland
}

\section{Abstract}

This paper analyses the discourses of two movements opposing National Park projects in Switzerland, focusing on their strategies and the political causes of their actions. Five in-depth qualitative interviews were conducted with the leaders of the opponents of Adula Park and Locarnese Park. The results reveal a cultural war between nature conservation advocates and park opponents. The existence of this radical opposition prevented bottom-up schemes from working. Further studies should aim to better understand the causes of this malaise in order to facilitate greater acceptance of new Protected Areas.

\section{Profile}

Protected area

proposed Adula Park \&

\section{Locarnese Park}

\section{Mountain range}

\section{Alps, Switzerland}

\section{Introduction}

This paper is the last of a tryptic of studies I have carried out on the rejection of two Swiss national park projects (Cometta, forthcoming 2020). It aims to understand the broader ideological links between two groups of opponents, highlighting their shared values. In doing so, it paves the way for a broader understanding of issues related to the implementation of Protected Areas (PAs).

The hypothesis of a second or reflexive modernity (Beck \& Lau 2005; Zuboff 2018) is fundamental for understanding the drive for personal, individual, development in contemporary society. Such personalization generates tensions at the political level (Flanagan 2003), which translate into an increasing difficulty for the state to fully satisfy individual needs, and hence into a loss of political legitimacy (Bobbio 1995). Some scholars, to define the tensions between the expectations of different social groups and the clash between their ontologies, have referred to "culture wars". This notion applies in particular to the battles between universalism and multiculturalism in the United States in the $20^{\text {th }}$ century, although it tends to simplify the historical process (Singh 1998). I suggest that the concept can help shed light on some aspects of the controversies around the creation of PAs. The impossibility of establishing fruitful dialogue and reciprocal understanding - that is, discursive asynchrony (Cometta 2020) - and the increase in aggressiveness in communication to strengthen intra-group unity at the expense of social unity (Garcés-Conejos Blitvich 2009) are in fact common to both culture wars and the debates on the creation of new PAs. Within this framework, the study of social polarization underlines the causes of the rejection of PAs. The repeated failures of some PAs' negotiations in Western Europe (Depraz \& Laslaz 2017; Michel \& Bruggman 2019) point up the failure of arbitration and negotiation as democratic instruments (Mouffe 2013).

The notion of culture wars hints at the attempt by white middle-class males to regain possession of the hegemonic media space - their privileged position. I suggest that a parallel can be made with discussions on PAs in Switzerland, where the centrality of mountain villages is at stake. They have long been at the centre of Swiss identity (Diener et al. 2006; Salomon Cavin \& Marchand 2010), but the neoliberal socio-territorial paradigm (Haughton et al. 2013; Häussermann 2005; Ranci 2017) has increasingly eroded their historical privileges: pre-neoliberal anti-centralist and anti-urban policies had higher per capita expenditure for mountain villages. The reaction against the proposals for the creation of PAs can be understood as the will to counter the new institutional paradigm, defending traditional values and privileges: an example of the conflict between city and country. As in culture wars, the creation of PAs provokes disagreement about how to express the founding values of a nation (Jensen 1995); thus, the disagreement should not be understood simply as a punctual opposition to a territorial project.

In this paper I will be using this framework to analyse the motivations of the group leaders who opposed two National Park projects in Switzerland. I will try to show how anti-PA groups emerged, organized themselves and communicated, and how the political causes of this phenomenon can be interpreted.

\section{Study area}

This paper focuses on the rejection of two National Park projects in Ticino Canton, Switzerland. Both projects competed to be the second Swiss National Park, under IUCN category II; in accordance with the Ordinance on Parks of National Importance, they were put to the vote in the municipalities involved. 


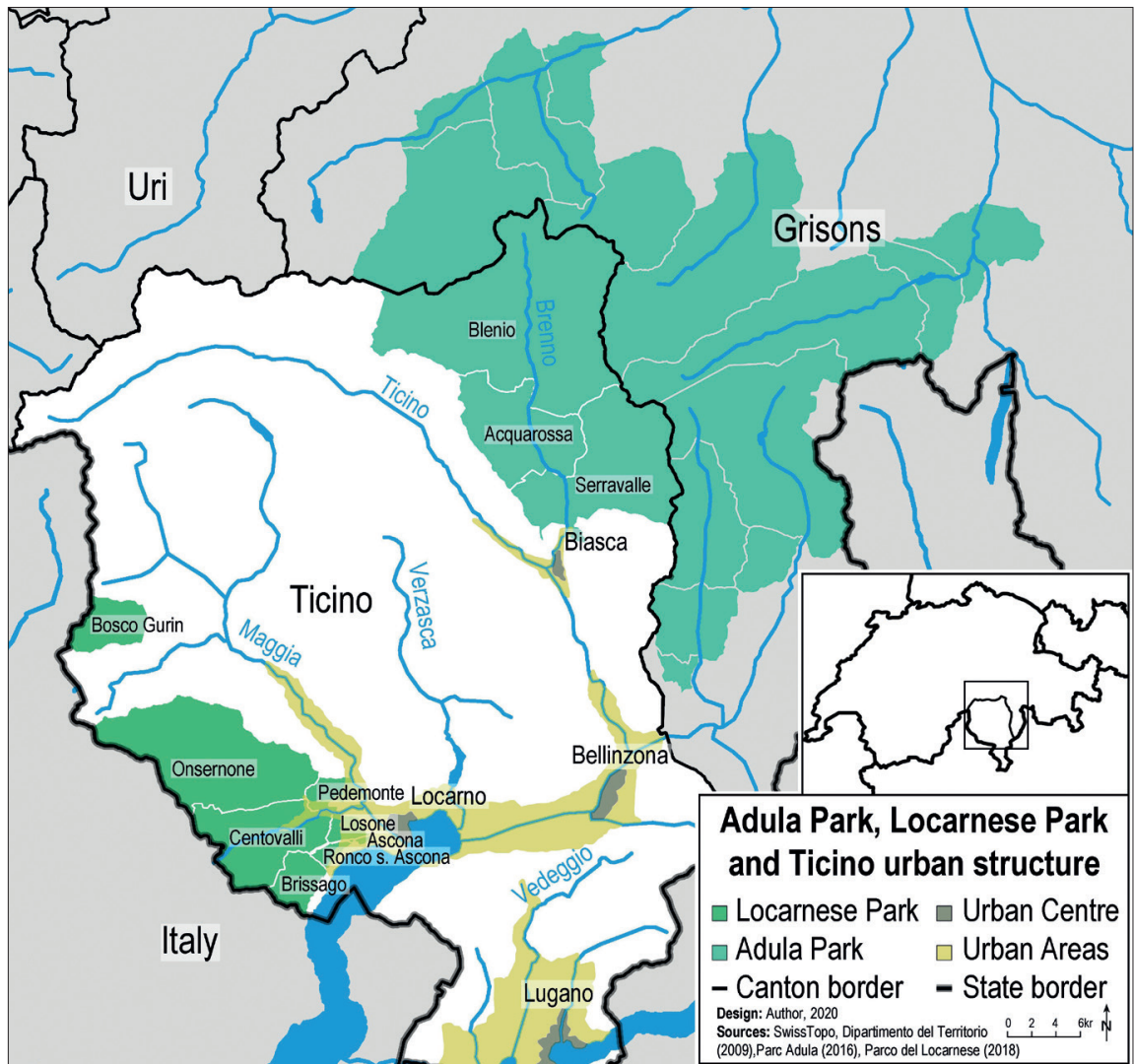

Figure 1 - Proposed extents of Adula Park and Locarnese Park, and the Ticino urbanized areas. The white lines within the green areas indicate the municipalitie borders.

Adula Park (Mount Adula's central peak is located at $46^{\circ} 29^{\prime} \mathrm{N}, 9^{\circ} 2^{\prime} \mathrm{E}$ ) was an inter-cantonal project (Ticino and Grisons) comprising 17 municipalities from three different linguistic areas, with a population of around 16000 people; just three of the municipalities and almost 6000 people in the Ticino valley were involved. The project was rejected in November 2016. For additional context, there is an extensive body of literature on this case (Cometta 2020; Michel 2017, 2019; Michel \& Backhaus 2019; Michel \& Bruggman 2019).

Locarnese Park, which is centred roughly on the village of Mosogno $\left(46^{\circ} 11^{\prime} \mathrm{N}, 8^{\circ} 38^{\prime} \mathrm{E}\right)$, was a Ticinese project, which, after a difficult initial phase and the withdrawal of a number of municipalities, finally included 8 municipalities with a population of about 19000 people on the outskirts of the city of Locarno. In June 2018 the project was rejected by 6 of the $8 \mathrm{mu}$ - nicipalities by a narrow majority. Currently, there is almost no literature on this case (Cometta, forthcoming).

\section{Methodology}

This research is based on 5 qualitative semi-directive interviews with leaders of the anti-PA groups. To identify them, a preliminary search was carried out in the cantonal Digital Archive of newspapers and periodicals. The two most important cantonal newspapers - Corriere del Ticino and laRegione - were searched using the following keywords: Parc Adula, PA, Parco, Parco Nazionale del Locarnese, PNL, Parco del Locarnese. The results were skimmed to identify only those articles and letters from readers that were relevant to the topic (Figure 2). Reading the 464 texts (334 items published between 01.01.2004 and 31.12.2017 for Adula Park, and 130 items published between 01.01.2000

Table 1 - Biographical data of interviewees.

\begin{tabular}{|l|l|l|l|}
\cline { 2 - 3 } \multicolumn{1}{c|}{} & Interviewees & \multicolumn{2}{|c|}{$\begin{array}{l}\text { Rdula } \\
\text { Park }\end{array}$} \\
\cline { 2 - 4 } & $\begin{array}{l}\text { Town council member and later village } \\
\text { mayor (referred in the results as TC1) }\end{array}$ & \multicolumn{1}{|c|}{ Cantonal MP, hunter (MP2) } & $\begin{array}{l}\text { Former town council member, resides } \\
\text { outside the proposed Park area (TC3) }\end{array}$ \\
\hline \multirow{2}{*}{$\begin{array}{l}\text { Locarnese } \\
\text { Park }\end{array}$} & $\begin{array}{l}\text { Emeritus Professor and former senior cantonal official, resides } \\
\text { outside the proposed Park area (EP4) }\end{array}$ & $\begin{array}{l}\text { Member of a local civic corporation that owns public land in } \\
\text { the proposed Park area, resides outside the proposed Park } \\
\text { area (P5) }\end{array}$ \\
\cline { 2 - 4 } & $\begin{array}{l}\text { Self-defined former left-wing sympathizer; set himself against } \\
\text { political fair-play }\end{array}$ & Identifies himself with right-wing values \\
\hline
\end{tabular}




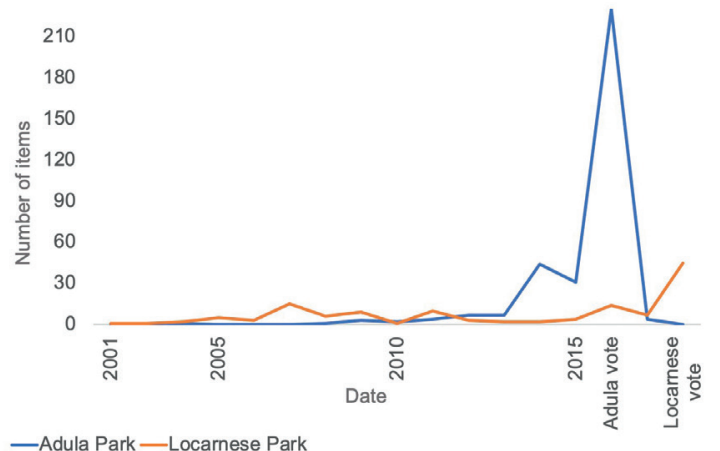

—Adula Park — Locarnese Park

Figure 2 - Number of newspaper texts analysed, based on year of publication.

and 31.12.2018 for Locarnese Park) led to the identification of the eight leaders of the movements opposing the two parks: 3 for Locarnese Park and 5 for Adula Park. This paper focuses mainly on the leaders' perspectives and narratives (Ferreira 2014; Robinson 2014), which are important for understanding local people's opposition to the projects (Moscovici 1988, p. 224).

Five in-depth semi-structured qualitative interviews (Duchesne 1996; Mercuri Chapuis 2015; Pekarek 1993; Torkar et al. 2011) were carried out, in accordance with the saturation criterion (Bowen 2008; Guest et al. 2006) - 3 interviews for Adula Park and 2 for Locarnese Park. Repetitions across the answers, especially in the case of Locarnese Park, suggest that little information about the anti-park leadership perspective had been omitted, demonstrating the soundness of the choice of leaders who were interviewed (Marshall et al. 2013).

The interviews lasted approximately an hour and a quarter, and followed a protocol covering various aspects but leaving the interviewee ample freedom of answer. The interviews were recorded, and the answers received were partly transcribed. Every aspect of the analysis was discussed by a group of 3 researchers to ensure its reliability (Sykes 1991) without falling into excessive quantification (Stenbacka 2001).

\section{Results}

The questions posed in the semi-directive interviews focused mainly on two aspects: the organization and communication of the groups opposing the Parks, and the causes and consequences of their victories. According to their leaders, the organization of the movements was mostly spontaneous, and their communicative approach used agressive tactics including insults, mockery and spreading rumours about PA's board of directors. Almost everyone pointed out that the vote split local communities deeply.

\section{The birth of dissent}

TC3 argues that during the 16-year gestation period of the Park project, he was repeatedly urged by other citizens to organize some form of opposition to the Park, because they were afraid to expose themselves publicly. TC1 maintains that the movement arose spontaneously from a small group of like-minded people, and that it took root particularly in Blenio. She says that there have been only sporadic contacts with Park-opponents from other language regions (particularly those of Surselva), while MP2 suggests that there were good relations with this German-speaking group.

In the Locarnese case, P5 claims that dissent was already present, but its organization started when he opened a Facebook page against the Park. The page allowed EP4 to get in touch with P5 and form a small group of three activists. Both argue that other opponents, who were living in places where the Park was to be established, were afraid of retaliation if they exposed themselves publicly.

All interviewees state that there have been hardly any contacts or alliances between the opponents of the two Parks, despite all expressing mutual sympathy. EP4 claims that being few in number allowed the core group of Locarnese opponents to be more agile, speeding up decision-making and allowing continuous internal discussion. TC3 argues that the Locarnese group was significantly more structured, while Blenio's group was less organized. While all five interviewees maintain that they were not directly inspired by any particular political movement, EP4 concedes that support came mostly from the right wing. Furthermore, MP2, TC3 and P5 argue that the vote on Adula Park (November 2016) influenced the vote on Locarnese Park (June 2018): the dissenting local voices surrounding Adula raised doubts about the validity of a $\mathrm{Na}$ tional Park project for the Alpine territories in general.

The communication battle

Regarding Adula Park, TC1 claims that the Park's promoters had a huge budget and the support of communications professionals to articulate their message. By contrast, those against the Park had only improvised means (newspaper articles, banners, social media posts). According to MP2, the promoters were looking for a consensus at grass-roots level across the canton, while opponents focused on the local community that was eligible to vote. Where Locarnese Park is concerned, EP4 claims that the promoters spent around 700000 francs on promoting the project, while those campaigning against the Park spent only 20000 . To counter this capital difference, opponents focused on direct, provocative messages, using irony and emotive language. All respondents indicate that the public debate was aggressive and quite emotional. EP4 highlights the difficulty that opponents felt in being able to participate in the debate. Both leaders of those who were against the Locarnese project perceived an attempt to censor them, especially by the newspapers, which in their view were supportive of the Park. In the Adula Park debate, on the other hand, the opponents felt less ostracized by the newspapers, 
except for TC3, who claims to have had to publish some letters under false names. Everyone points out that social media played a key role in communicating the opinions of opponents, especially to young people. In the Locarnese case, both leaders insist on the absence of censorship in social media and the possibility of communicating via video as an effective way to quickly present strong arguments against the project through evocative images. In the case of Adula Park, MP2 stresses that social media acted as catalysts for confrontation, encouraging aggressive language and personal verbal attacks.

According to the Bleniese leaders, their greatest communicative victory was to present concrete arguments against the project, disproving what they believed to be the lies of the promoters and insisting on ideas of autonomy and freedom. For the Locarnese, their greatest success was being able to contradict the promoters using irony and sarcasm - through videos and photos on social networks, and through a printed pamphlet addressed to all the inhabitants of the villages involved.

In the opinion of Adula Park's opponents, the promoters' major mistakes were the vagueness of their plans and the abstract nature of their promises, while they also tried to gain the support of prominent political personalities instead of attempting to convince local people of the benefits that the Park would bring. Another problem reported relates to the longevity of the Park. The continued existence of any PA that was created would be subject to a vote after ten years, but the Park's opponents were convinced that it would not be dismantled even if a majority of local people voted against retaining the area. Opponents, however, had no factual evidence for any such strategy, and their claim was repeatedly refuted by cantonal and federal authorities. The fact that the project was promoted mainly by environmental organizations and was therefore not perceived as being aimed at local development but at nature conservation is reported as a further major mistake.

As for Locarnese Park, opponents of Adula Park argue that the promoters' worst faults were their arrogance, their confidence that they would win, and their lack of preparation for the public debates. The constant negotiations between various stakeholders and the attempt to find compromises that would suit everyone, which were presented by the promoters as evidence that the Park would respect the local population and their needs, were instead interpreted by its opponents as a lack of consistency.

The consequences of the vote

When asked whether the local community came out strengthened or weakened by the vote, almost everyone admits a deep split within the population. MP2 points out that the older generation is the most bound to the ideals of the municipalities' autonomy and freedom. P5 indicates how the vote reflected the existence of two opposing but internally very cohesive groups among the population. TC3 argues that the vote led to the breaking of relations of friendship, and EP4 maintains that these enmities, in such a small social context, will last at least a generation. Finally, TC1 mentions tensions in the collaboration between the municipal councils that voted for and against the project.

\section{Imagining the enemies}

The last section of the interviews focused on how the leaders of the Parks' opponents imagine their political opponents - i. e. the Parks' promoters, supporters and their values - and what broader significance they attribute to the vote. For TC1, their direct opponent was the world of environmentalism and "extreme nature conservation". TC3 points to Adula Park's board of directors as their main adversary, followed by municipalities and town councillors, "who in small villages are all relatives". Opponents accused such figures of trying to buy the support of local people, notably farmers, by emphasizing the grants and subsidies that the Park and other authorities would make available to them. MP2 states that the Park's proponents have a very visible media presence and a considerable amount of money at their disposal, and continue to pursue "an excessively abstract idea". For EP4 the promoters of the Locarnese Park were a few people in good faith and about 200 who were seeking enrichment and public subsidies, while the general public who supported the project was basically in good faith. P5 points out that the Park's management did not believe sufficiently in their project or its goals. According to P5, the management therefore refused to engage in public discussion to defend the Park, and left their communications vague so as to avoid confrontation with local interest groups. The Canton was another direct opponent one politically interested in the creation of National Parks to be used as a bargaining chip with the Federal Office for the Environment. Globally, however, P5 identifies their enemy as a "new ecological ideology with the aim of moving people away from nature" and of resettling the population in large urban areas.

In general, all the leaders recognized that their battle was not against the project of a National Park per se, but against a broader political strategy that they considered harmful to the inhabitants of the Alpine valleys. Those who were against the Locarnese Park, being considerably more organized, had a very structured overall vision of the enemy, which they identified as an ideology and labelled "fundamentalist" (common, in their opinion, to both the OECD and the IUCN), of environmental protection that wants to separate man and nature. In the analysis of EP4, former employees of international "mega-rich environmental organizations" have started working for the Federal Office for the Environment, radicalizing Swiss environmental policy towards a rewilding of Alpine areas. According to this interpretation, Adula Park and Locarnese Park would be followed by other PAs, to the point of transform- 
ing the entire Alpine region into a nature conservation area that would drive out its inhabitants. The leaders against Adula Park express similar feelings, albeit in a more general way. TC1 fears that such projects will turn the area into a living museum, expelling its inhabitants and restricting human activities. TC3 reiterates that the inhabitants of the valleys want to continue to be free, and that the Confederation must understand that it cannot turn the Alps into a Park.

\section{Discussion}

First, it is important to emphasize how the opponents represent themselves as spokespersons for a population frightened by censorship. In small villages, where, despite democratic rules, semi-oligarchies are in force and key power players seem immutable (RCT 1998 , p. 45), it is difficult to oppose the plans of the municipalities without being ostracized. The attempt by the two Parks to ally themselves with local authorities in order to show their closeness to the population seems to have had the opposite effect, alarming some of the residents. In turn, this allowed the opponents to set themselves up as heroes of the censored people, exploiting the communication mechanisms of victimization (Samet 2013), blame (Gerodimos 2015) and offensive language. Indeed, "the politics of resentment and victimization, so typical of populism, might resonate well with ethno-regional minorities that perceive a lack of recognition or fair treatment of their region by the state elites" (Heinisch et al. 2018, p. 928). The victory by the opponents suggests that a proportion of the population experienced the Park projects as an imposition by the central state despite bottom-up processes put in place by the promoters.

The example of the Locarnese, in particular, shows how the action of a tiny and well-coordinated group can frustrate the actions of a whole set of local and national institutions. To understand this surprising reversal, it may be useful to resort to the notion of the struggle for cultural hegemony. From a Gramscian perspective, society is divided into groups with conflicting interests and visions of reality (Gramsci 1971). Institutions, guarantors of social functioning, defend and propagate the vision of the hegemonic group, while non-hegemonic groups try to gain power and change the population's perception of reality.

In the two cases that interest us, we can observe how there are (at least) two distinct perspectives on PA projects: that of promoters and local institutions, who see them as proactive and democratic projects, and that of PA opponents, who see the projects as an imposition from above, by interests external to the valleys. This can also be described as a polemical representation of reality influenced by local identity requirements (Breakwell, 2001; Moscovici, 1988), and it is here that the notion of culture war can be useful.

During the second half of the $20^{\text {th }}$ century, the Ticino valleys received a great deal of aid to combat depopulation and ensure the survival of their villages. Numerous improvements to infrastructure were built, ample economic resources were guaranteed, and all this was carried out by local authorities themselves, who had decisional autonomy (Carloni 1998; Diener et al. 2006; Toppi 1998). Overall, therefore, the fragile position of the Alpine valleys has guaranteed them a privileged position with regard to public policies. Since the 1990s, however, with the advent of neo-liberal ideology within federal and cantonal institutions, a new paradigm has taken hold. More emphasis has since been placed on the profitability of public investment (Gunder 2010; Haughton et al. 2013; Ranci 2017). From this perspective, it therefore became absurd to continue to invest in the infrastructural development of areas that were too peripheral. Category II National Park projects - following the so-called neoliberal turn in nature conservation (Büscher \& Arsel 2012a, b) were a good alternative to redirect the development of Alpine valleys.

The shift in status and the loss of historical privileges fostered the emergence of a sense of victimhood. In the eyes of the population, it became possible to interpret the PA project as an expression of a wider strategy of transformation of the Alpine areas. EP4 and TC1 have emphasized how, in their opinion, this new ideology, which is carried out on a global scale by nature protection organizations, wants to erase the historical links between the inhabitants of the Alpine valleys and their territory, making all traces of human presence above $700 \mathrm{~m}$ a.s.l. disappear.

We can see a culture war developing before our eyes. For those opposed to them, National Parks imply submission to a strategy akin to the half-earth hypothesis (Vettese 2018; Wilson 2016). They stress that this kind of nature conservation is carried out at the expense of the most fragile communities, for example in Switzerland's poor and remote Alpine valleys, and therefore constitutes an injustice and prevarication by the wealthiest urban population. As Lele puts it with reference to the Global South: "the willingness to sacrifice concern for justice on the altar of global climate sustainability has been a hallmark of green growth thinking" (Lele 2020, p. 50; see also Büscher et al. 2017).

Hence, the two National Park projects possess a complexity of meanings that goes far beyond the concrete set of rules that each abides by. For instance, they may represent the loss of privileged status of the Alpine valleys, or even the sacrifice of peripheral communities by virtue of an unfair ecological realpolitik (see Pollin 2018, p. 21). This in turn demonstrates well how National Parks imply much more than might initially be thought: they can become pawns in the cultural war between ways of conceiving the relationship between humans and nature, or cities and the countryside. If a project for a new PA is not to be hijacked by controversy and populism, if the project is to be implemented, these are all aspects that need to be considered before embarking on the design of a new PA. 


\section{Conclusion}

Although they did not have close contacts with each other, the two opposition campaigns analysed here have many features in common. In particular, their ability to exploit victimization in their discourse and to use potentially offensive tactics results in the almost complete frustration of the promoters' attempts to construct bottom-up approaches. Another fundamental point in common is the existence of a culture war between advocates of nature conservation and those who see the creation of the new national parks as entailing the destruction of the human-nature relationship and the erasure of the history of Alpine communities. To constructively overcome these challenges is likely to take a long time, as well as considerable effort to better include those who feel excluded and marginalized. The first step towards this is an assessment of the quality of public debate: understanding whether the conditions for constructive discussion exist is a fundamental prerequisite for enabling bottomup processes to succeed. Thus, the social sciences can contribute significantly to the creation of new PAs. For example, additional qualitative as well as quantitative studies exploring the feelings of the population towards both concrete territorial projects and broader territorial policy over a sufficient time span could reveal possible changes in attitude more clearly and new opportunities for the creation of PAs. Furthermore, efforts should be made to include opponents of PAs at an early stage through working groups, so that dissent does not manifest itself only in a destructive form at the end of the process.

\section{Acknowledgements}

This work was supported by the Forum Landscape, Alps, Parks of the Swiss Academy of Sciences (SCNAT) and the Institute of Geography and Sustainability - University of Lausanne.

\section{References}

Beck, U., \& C. Lau 2005. Second modernity as a research agenda: Theoretical and empirical explorations in the 'meta-change' of modern society. The British Journal of Sociology 56(4): 525-557.

Bobbio, N. 1995. Stato, governo, società. Einaudi.

Bowen, G. A. (2008). Naturalistic inquiry and the saturation concept: A research note. Qualitative Research 8(1): 137-152.

Breakwell, G.M. 2001. Mental models and social representations of hazards: The significance of identity processes. Journal of Risk Research 4(4): 341-351. doi: 10.1080/13669870110062730

Büscher, B. \& M. Arsel 2012a. Introduction: Neoliberal conservation, uneven geographical development and the dynamics of contemporary capitalism.
Tijdschrift Voor Economische En Sociale Geografie 103(2): 129-135.

Büscher, B., \& M. Arsel 2012b. Nature'TM Inc.: Changes and Continuities in Neoliberal Conservation and Market-based Environmental Policy. Development and Change 43(1): 53-78.

Büscher, B., R. Fletcher, D. Brockington, C. Sandbrook, W.M. Adams, L. Campbell, C. Corson, W. Dressler, R. Duffy, N. Gray, G. Holmes, A. Kelly, E. Lunstrum, M. Ramutsindela \& K. Shanker 2017. Half-Earth or Whole Earth? Radical ideas for conservation, and their implications. Oryx 51(3): 407-410. doi: $10.1017 /$ S0030605316001228

Carloni, T. 1998. La grande trasformazione del territorio. In: Ceschi, R. (ed.), Storia del Cantone Ticino: Vol. II: 671-700. Stato del Cantone Ticino.

Cometta, M. (forthcoming). Insufficiencies of a bottom-up approach at the time of fake news. Parco del Locarnese refusal example. Revista Brasileira de Estudos Politicos.

Cometta, M. 2020. Protected Areas and Territorial Tensions: The Ticinese Case of Adula Park. eco.mont Journal on protected mountain areas research and management 12(2): 4-10.

Depraz, S. \& L. Laslaz 2017 . Conflicts, acceptance problems and participative policies in the national parks of the French Alps. eco.mont - Journal on protected mountain areas research and management 9 (1): 46-56.

Diener, R., J. Herzog, M. Meili, P. de Meuron \& C. Schmid 2006. Switzerland. An Urban Portrait.

Duchesne, S. 1996. Entretien non préstructuré, stratégie de recherche et étude des représentations. Ou: Peut-on déjà faire l'économie de l'entretien 'nondirectif' en sociologie ? Politix 9(35): 189-206.

Ferreira, V.S. 2014. Arts and tricks of comprehensive interview. Saúde e Sociedade 23(3). Available at: https://www.scielosp.org/article/sausoc/2014. v23n3/979-992/en/ (acessed 10.10.2020)

Flanagan, S. 2003. The new politics, culture wars, and the authoritarian-libertarian value change in advanced industrial democracies. Comparative Political Studies 36(3): 235-270.

Garcés-Conejos Blitvich, P. 2009. Impoliteness and identity in the American news media: The "Culture Wars”. Journal of Politeness Research 5: 273-303.

Gerodimos, R. 2015. The Ideology of Far Left Populism in Greece: Blame, Victimhood and Revenge in the Discourse of Greek Anarchists. Political Studies 63(3): 608-625. doi: 10.1111/1467-9248.12079

Gramsci, A. 1971. Prison Notebooks.

Guest, G., A. Bunce \& L. Johnson 2006. How Many Interviews Are Enough? An Experiment with Data Saturation and Variability. Field Methods 18(1): 59-82.

Gunder, M. 2010. Planning as the ideology of (neoliberal) space. Planning Theory 9(4): 298-314.

Haughton, G., P. Allmendinger \& S. Oosterlynck 2013. Spaces of neoliberal experimentation: Soft spaces, postpolitics, and neoliberal governmentality. Environment and Planning 45: 217-234. 
Häussermann, H. 2005. The end of the European City? European Review 13(2): 237-249. doi: 10.1017/ S1062798705000372

Heinisch, R., E. Massetti \& O. Mazzoleni 2018. Populism and ethno-territorial politics in European multi-level systems. Comparative European Politics 16(6): 923-936. doi: 10.1057/s41295-018-0142-1

Jensen, R. 1995. The Culture Wars, 1965-1995: A Historian's Map. Journal of Social History 29: 17-37.

Lele, S. 2020. Environment and Well-being. A Perspective from the Global South. New Left Review 123: 41-63.

Marshall, B., P. Cardon, A. Poddar \& R. Fontenot 2013. Does Sample Size Matter in Qualitative Research?: A Review of Qualitative Interviews in is Research. Journal of Computer Information Systems 54(1): 11-22.

Mercuri Chapuis, S. 2015. Using semi-directive interview: An analysis of the power and social responsability of researchers. In: Cassar, V. (ed.), Proceedings of the $14^{\text {th }}$ European Conference on Research Methodology for Business and Management Studies: 282-289.

Michel, A.H. 2017. 'What is a national park for?' Principles of worth in a Swiss national park project. $6^{\text {th }}$ Symposium for Research in Protected Areas, Vienna.

Michel, A.H. 2019. How conceptions of equity and justice shape national park negotiations: The case of Parc Adula, Switzerland. eco.mont - Journal on protected mountain areas research and management 11(1): 25-31.

Michel, A.H. \& N. Backhaus 2019. Unravelling Reasons for the Non-Establishment of Protected Areas: Justification Regimes and Principles of Worth in a Swiss National Park Project. Environmental Values 28(2): 171-190. doi: 10.3197/096327119X155152674 18511

Michel, A.H. \& A. Bruggman 2019. Conflicting Discourses: Understanding the Rejection of a Swiss National Park Project Using Data Analysis Triangulation. Mountain Research and Development 39(1). doi: 10.1659/MRD-JOURNAL-D-18-00081.1

Moscovici, S. 1988. Notes towards a description of Social Representations. European Journal of Social Psychology 18(3): 211-250. doi: 10.1002/ejsp.2420180303

Mouffe, C. 2013. Agonistics. Thinking the world politically.

Pekarek, S. 1993. Gestion des rôles dans l'interview semi-directive de recherche: Activités de guidage et travail relationnel de l'intervieweur. Bulletin CILA 57: 85-103.

Pollin, R. 2018. De-Growth vs a Green New Deal. New Left Review 112: 5-25.
Ranci, C. 2017. Neoliberalism and the European city: Reshaping the competitiveness/social cohesion nexus. In: Morel Journel, C. \& G. Pinson (eds.), Debating the neoliberal city: 136-152.

RCT. 1998. Il Cantone ed i suoi comuni. L'esigenza di cambiare.

Robinson, O.C. 2014. Sampling in Interview-Based Qualitative Research: A Theoretical and Practical Guide. Qualitative Research in Psychology 11(1): 25-41.

Salomon Cavin, J. \& B. Marchand 2010. Antiurbain: Origines et conséquences de l'urbaphobie. Presses polytechniques et universitaires romandes.

Samet, R. 2013. The photographer's body: Populism, polarization, and the uses of victimhood in Venezuela: The photographer's body. American Ethnologist 40(3): 525-539. doi: 10.1111/amet.12037

Singh, N.P. 1998. Culture/Wars: Recoding Empire in an Age of Democracy. American Quarterly 50(3): 471-522.

Stenbacka, C. 2001. Qualitative research requires quality concepts of its own. Management Decision 39(7): 551-556. doi: 10.1108/EUM0000000005801

Sykes, W. 1991. Taking Stock: Issues from the Literature on Validity and Reliability in Qualitative Research. Market Research Society. Journal 33(1): 1-11. doi: 10.1177/147078539103300101

Toppi, S. 1998. La crescita economica (1945-1975): La scommessa industriale. In: Ceschi, R. (ed.), Storia del Cantone Ticino Vol. II: 593-614. Stato del Cantone Ticino.

Torkar, G., B. Zimmermann \& T. Willebrand 2011. Qualitatives Interviews in Human Dimensions Studies About Nature Conservation. Varstvo Narave 25: 39-52.

Vettese, T. 2018. To Freeze the Thames. Natural Geo-Engineering and Biodiversity. New Left Review 111: 63-86.

Wilson, E.O. 2016. Half-earth: Ourplanet's fight for life (First edition).

Zuboff, S. 2018. The age of surveillance capitalism: The fight for a buman future at the new frontier of power.

\section{Author}

\section{Mosè Cometta}

is working as a post-doc at the University of Turin. His main research interests are identity construction dynamics, cultural hegemony struggles, and political and territorial philosophy. E-mail: mose.cometta@ unil.ch. ORCID-ID: https://orcid.org/0000-00018700-2030 